\title{
Momento de caridade
}

Maria Braga Barbosa ${ }^{1}$

É necessário fazer o bem nesta vida. É bom, é sensato e mesmo lógico o ser humano em defesa do outro da espécie.

Foi por isso que quando vi aquele velho caquético gemente, com a perna quebrada tracionada, urinado, faminto, sozinho, sobre uma maca sem colchão há três dias, incapaz de informar aos outros sobre sua dor, num pronto socorro de loucos transeuntes embaraçados pelo caos do sistema... Algo era preciso ser feito. Naquele lugar eu geralmente fazia o bem. Às vezes um bem melhor que o outro, às vezes um bem medíocre. Então me apareceu a chance de fazer um bem colossal, um bem obra prima!

Arregacei as mangas, mas o primeiro obstáculo encontrado foi a total falta de colchão e lençol. Em pronto socorro de hospital público isso geralmente acontece. Saí a campear pelo hospital inteiro, haveria de conseguir colchão e lençol fosse como fosse. Consegui os lençóis, mas colchão não havia nem metade de um, e os pacientes sentados pelos bancos e pelo chão já se amontoavam.

Continuei de enfermaria em enfermaria, pensamento fixo no velhinho que sofria há passos dali. O tempo passando e o trabalho se acumulando... mas não desisti. Então eis que me aparece no quarto 03 uma maca sem ninguém, pronta, com colchão e tudo! Os acompanhantes informaram que o paciente daquela maca era um alcoólatra em síndrome de abstinência que

${ }^{1}$ Mestranda em Literatura pela UnB - Universidade de Brasilia . Pesquisa: "Uma Paixão no Deserto - o conto de Balzac como metáfora do choque de culturas no colonialismo". Contato: marbrag@gmail.com 
estava passeando no jardim. Meu ímpeto de justiça se inflamou. "Alcoólatra?", pensei, "Pois ele está muito bem passeando, não precisa da maca. Bêbado dorme até no chão com muito conforto". E sem mais espera levei aquele colchão mesmo: "Com licença que ali no corredor tem um doente de verdade, sem saúde pra beber e sem saúde pra andar em jardim". Ninguém se objetou.

Então, com a ajuda de um colega, comecei a empreitada. Não cabe à medicina opor-se à morte, mas lutar contra a doença para prolongar a vida. Não cabe à enfermagem tratar a doença, mas oferecer conforto ao paciente. Tudo tem um desfecho na benevolência. Ciências cristãs capitalistas. E daí? O que eu devia era pensar menos e agir mais. Anunciei ao velho que o deixaria mais confortável. "Velho", não, paciente. Limpei o paciente, acomodei com muito custo o colchão e o lençol sob seu corpo decrépito, manipulando a perna quebrada, Acomodei sua cabeça, ofereci-lhe alimento, fiz o medicamento para dor e fiquei naquele contentamento de missão cumprida, sobretudo porque o velho, mesmo com rebaixada capacidade comunicativa, teve uma palavra rouca de agradecimento. Ao final, o retiramos do corredor e o colocamos exatamente na enfermaria 03 , junto ao alcoólatra que tinha ficado com uma maca sem colchão.

Horas mais tarde quando retorno para fazer a medicação daquela enfermaria, o paciente alcoólatra já estava no quarto, tranquilo, regresso de seu passeio. Estava sentado numa cadeira e recebera a visita de suas irmãs que, em volta dele, lhe arrumavam os cabelos e faziam massagem. Esperei que elas fossem reclamar o colchão surrupiado, mas elas conversavam descontraidamente com os outros pacientes e acompanhantes da enfermaria. Nesse momento, ouvi que o velho também conversava, mas só para si mesmo, em voz baixa, olhando para o teto, indiferente com a presença das outras pessoas. As irmãs do paciente alcoólatra diziam: "Esse aqui, vocês nem imaginam que pessoa boa que é. Amigo de todo mundo, carinhoso com a família, honesto com os negócios dele, não tem inimizades, não tem. Sempre foi o filho e o irmão mais afetuoso... Meu Deus... pena que esse vício, essa fraqueza... ele não consegue largar... É só o defeito que ele tem... Mas a gente nunca perde a fé que nosso irmão um dia vai se recuperar disso..." Ao passo que o velho, do outro lado, perto da parede, dizia, quase em cochicho, coisas que custei a entender: "Me lembra... Foi... eu fiz muita maldade na minha vida. Fiz... Matei um bocado de gente. Matei... matei gente nova e gente 
velha... Ô que eu já judiei dos outros... Já desrespeitei minha irmã, abusei dela... Ô que eu já fiz nessa vida...” Os outros não ouviam isso. Somente eu porque estava bem próxima dele e o olhava nos olhos, na face, nos olhos, na face... Pasmei devagarzinho. Tão inofensivo naquele momento, o rosto enrugado digno de confiança, respeito e piedade. Era um velho, um vovô, um velhinho, outra categoria de ser humano à qual nunca se atribui o papel de vilão. Velhinhos não são assassinos. Então não era ele o mesmo réu confesso apenas porque seu corpo já era incapaz de conduzi-lo ao crime e sua mente inapta a maquinar o mal?

Sempre odiei as ironias, mas sempre aprendi tanto com elas. Voltei para o posto muito revolvendo pensamentos. Aí deixo cair a capa de heroína: absorvi o culpado e condenei o inocente. Ainda assim, ninguém pode afirmar que eu não fiz o bem, esse bem que vem nos manuais do cidadão e do cristão. No entanto, talvez eu ainda pague pelo erro de ter interferido na natural pena a ser cumprida por um alto criminoso só porque ele estava ali vestido nas finas lãs da inocência senil. Enganos desse mundo, bem e mal, afinal de contas, são um a cara do outro. 